УДК 373.31:37.012

DOI https://doi.org/10.32782/apv/2021.3.10

\title{
олена ІЛьӥнА
}

кандидат педагогічних наук, викладач кафедри педагогіки, психології, початкової освіти та освітнього менеджменту, К3 «Харківська гуманітарно-педагогічна академія» Харківської обласної ради, пров. Руставелі, 7, м. Харків, Украӥна, 61050

ORCID: 0000-0003-1951-4311

Бібліографічний опис статті: Ільїна, О. (2021). Використання технології проєктного навчання в Новій українській школі. Acta Paedagogica Volynienses, 3, 63-68, doi:

\section{ВИКОРИСТАННЯ ТЕХНОЛОГІЇ ПРОСКТНОГО НАВЧАННЯ В НОВІЙ УКРАЇНСЬКІЙ ШКОЛІ}

\begin{abstract}
У статті розглядається проблема використання технологї̈ проєктного навчання в Новій українській школі. Зазначено, що в Новій украӥнській школі пріоритетом стає формування загальноосвітніх умінь $і$ навичок, а також способів діяльності, рівень освоєння яких в значній мірі визначає успішність всього подальшого навчання. Метою статті є дослідження теоретичних основ та особливостей використання технології проєктного навчання в Новій українській школі. Під час аналізу поняття «проєктна технологія», було сформулюване робоче визначення проєктної технологї молодших школярів як спільна навчально-пізнавальна, творча ігрова діяльність учнів, щзо має спільну мету, узгоджені способи діяльності, спрямовані на досягнення загального результату. 3'ясовано, що в основі методу лежить розвиток пізнавальних інтересів учнів, умінь самостійно конструювати свої знання, орієнтуватися в інформаиійному просторі, показувати свої знання в питаннях, пов'язаних з темою проєкту. Встановлено, шзо у процесі організації проєктної діяльності учнів учитель виступає в різних рольових позиціях. Представлена класифікація проєктів: за тривалістю часу, за рівнем інтеграції, за способом переважної діяльності, за способом переважної діяльності учнів. Визначені етапи, відповідні структурі освітньої діяльності: мотиваційний, підготовчий, інформаційно-операційний, рефлексивно-оцінний. 3 метою оптимізаціі проєктної діяльності дітей запропонований алгоритм. Для прикладу був розглянутий проєкт по темі «Річки та водойми нашої місиевості», який створювався та реалізовувався на інтегрованому курсі «Я досліджую світ». Зроблено висновки, щэо иінність проєктної діяльності полягає в збагаченні суб'єктивного досвіду дітей новими знаннями і способами діяльності, а також використання проєктів дозволяє розвивати творчі здібності, логічне мислення, прагнення самому відкривати нові знання і вміння виявляти їх в сучасній дійсності.
\end{abstract}

Ключові слова: проєкт, проєктна технологія, проєктна діяльність, молодші школярі, вчитель, Нова украӥнська школа.

\section{Olena ILINA}

Candidate of Pedagogic Sciences, Lecturer at the Department of Pedagogy, Psychology, Primary Education and Educational Management, Municipal Institution "Kharkiv Humanitarian and Pedagogical Academy" of the Kharkiv Regional Council, Rustaveli lane, 7, Kharkiv, Ukraine, 61050

ORCID: 0000-0003-1951-4311

To cite this article: Ilina, O. (2021). Vykorystannya tekhnolohiyi proyektnoho navchannya v Noviy ukrayins'kiy shkoli [Use of project learning technology in the New Ukrainian school]. Acta Paedagogica Volynienses, 3, 63-68, doi: https://doi.org/10.32782/apv/2021.3.10

\section{USE OF PROJECT LEARNING TECHNOLOGY IN THE NEW UKRAINIAN SCHOOL}

The article considers the problem of using project learning technology in the New Ukrainian school. It is noted that in the New Ukrainian School the priority is the formation of general skills and abilities, as well as methods of activity, the level of development of which largely determines the success of all further education. The aim of the article is to study the theoretical foundations and features of the use of project-based learning technology in the New Ukrainian School. When analyzing the concept of "project technology", a working definition of project technology of primary schoolchildren was formulated as a joint educational and cognitive, creative play activities of students with a common goal, agreed ways of working to achieve the overall result. It was found that the method is based on the development of cognitive interests of students, the ability to independently construct their knowledge, navigate in the information space, show their knowledge in matters related to the topic of the project. It is established that in the process of organizing students' project activities, the teacher acts in different role positions. The classification of projects is presented: by duration of time, by 
level of integration, by way of predominant activity, by way of predominant activity of students. The stages corresponding to the structure of educational activity are determined: motivational, preparatory, information-operational, reflexiveevaluative. In order to optimize the project activities of children, an algorithm is proposed. For example, a project on "Rivers and reservoirs of our area» was considered, which was created and implemented in the integrated course "I explore the world». It is concluded that the value of project activities lies in enriching the subjective experience of children with new knowledge and methods of activity, and the use of projects allows to develop creative abilities, logical thinking, the desire to discover new knowledge and the ability to discover them in modern reality.

Key words: project, project technology, project activity, primary schoolchildren, teacher, New Ukrainian school.

Актуальність проблеми. У процесі модернізації системи освіти основним потреби і умінь самостійно здобувати знання, а також застосовувати їх в практичній життєдіяльності.

В Новій українській школі пріоритетом стає формування загальноосвітніх умінь і навичок, а також способів діяльності, рівень освоєння яких в значній мірі визначає успішність всього подальшого навчання (Bibik, 2018).

Натепер усе більш актуальним в освітньому процесі стає використання в навчанні прийомів і методів, які формують вміння самостійно здобувати нові знання, збирати необхідну інформацію, висувати гіпотези, робити висновки й умовиводи. Загальна дидактика та приватні методики в рамках освітніх компонентів закликають вирішувати проблеми, пов'язані з розвитком у школярів умінь і навичок самостійності та саморозвитку. Проблема вибору необхідного методу роботи виникала перед педагогами завжди. Але в нових умовах нам необхідні нові форм і методи навчання, оновлення змісту освіти що дозволяють по-новому організувати процес навчання, взаємини між учителем і учнем. В останні роки цю проблему в початковій школі намагаються вирішувати, зокрема через організацію проєктної діяльності.

Аналіз останніх досліджень і публікацій. Метод проєктів не є принципово новим у світовій педагогіці. Він був запропонований і розроблений в 1920-і рр. американським філософом і педагогом Дж. Дьюї на основі гуманістичних ідей і розвинений його учнем. Дж. Дьюї у своїх роботах розкривав концептуальні засади, принципи та етапи організації проєктної діяльності, пропонував будувати навчання на активній основі, використовуючи цілеспрямовану діяльність учнів з урахуванням їх особистої зацікавленості в знаннях і отримуючи в результаті реальний результат.

Питаннями проєктних технологій переймаються і українські дослідники Н. Борисова, Т. Качеровська, О. Коваленко, О. Пєхота, О. Пометун, Г. Романова, С. Сисоєва та інші.
Поняття «проєктна технологія», «метод проєктів», «проєктна діяльність» у сучасній педагогіці має багато визначень. Так $Є$. Коваленко під методом проєкту розуміє спосіб організації самостійної діяльності здобувачів освіти, спрямований на вирішення завдань освітнього процесу, що інтегрує в собі проблемний підхід, групові методи, рефлексивні, презентаційні, дослідницькі, пошукові й інші методики (Коваленко, 2011: 14-18). На думку Л. Лук'янова, метод проєктів це особистісноорієнтований метод навчання, заснований на самостійній діяльності учнів щодо розробки проблеми й оформлення ії практичного результату (Лук'янова, 2009, с. 16-21). Схоже визначення дає I. Зимня, відбиваючи найважливішу особливість методу проєктів: «Проєкт - самостійно планована й реалізована учнями робота, у якій мовленнєве спілкування вплетене в інтелектуально-емоційний контекст іншої діяльності» (Зимняя, 1991, с. 9-12).

Мета дослідження. Метою статті $є$ дослідження теоретичних основ та особливостей використання технології проєктного навчання в Новій українській школі.

Виклад основного матеріалу дослідження. Аналіз поняття «проєктна технологія» дає можливість сформулювати робоче визначення: проєктна технологія молодших школярів - це спільна навчально-пізнавальна, творча ігрова діяльність учнів, що має спільну мету, узгоджені способи діяльності, спрямовані на досягнення загального результату. Водночас у дітей має бути сформоване уявлення про кінцевий продукт діяльності, етапах проєктування (вироблення концепції, визначення цілей і завдань проєкту, доступних i оптимальних ресурсів діяльності, створення плану) і реалізації проєкту, включаючи його осмислення і рефлексію діяльності (Білик, 2013, с. 6-8).

Проєктна технологія навчання передбачає процес розробки і створення проєкту. В основі методу лежить розвиток пізнавальних інтересів учнів, умінь самостійно конструювати свої зна- 
ння, орієнтуватися в інформаційному просторі, показувати свої знання в питаннях, пов'язаних 3 темою проєкту.

Систематичне включення молодших школярів в проєктну діяльність забезпечує формування у них ключових компетентностей: вміння вчитися, загальнокультурної, навчально-пізнавальної, інформаційної, комунікативної, соціальної, самовдосконалення.

Доцільно в процесі роботи над проєктом проводити 3 молодшими школярами екскурciï, прогулянки-спостереження, соціальні акції. Водночас інтерес становить опитування, інтерв'ювання учнями окремих осіб, для яких призначений проєкт.

Вчителю, який організовує проєктну діяльність дітей, треба знати, що цей вид діяльності вимагає від нього створення умов для розширення пізнавальних інтересів дітей, можливості ix самоосвіти в процесі практичного застосування знань.

Саме вчитель стимулює самостійну активність учнів, їх кмітливість і винахідливість, підвищує мотивацію учнів, організовує доступ до інформаційних ресурсів, дає чіткий аналіз результатів виконаного проєкту. Але вчителю, що використовує в організації педагогічного процесу метод проєктів, потрібно знати проблеми, що виникають в ході роботи: це недо- статнє, поверхневе усвідомлення суті проєктної діяльності, ролі кожного учня в ній, невміння запобігати труднощі, неготовність багатьох учнів до проєктування через індивідуальні здібності. Якщо вчитель не навчиться оперативно реагувати на них, то результати проєктного методу будуть неефективні (Бєляєв, 2009, с. 31-34).

У процесі організації проєктної діяльності учнів учитель виступає в різних рольових позиціях:

- проєктувальник - проєктує основні положення проєктної діяльності учнів до її виконання;

- фасилітатор-консультант - спонукає до самостійного пошуку завдань і їх рішень, володіє умінням ставити запитання дослідницького типу, водночас створює доброзичливу атмосферу, заохочуючи учнів висловлювати свою думку;

- координатор - допомагає відстежити рух пошуку, пов'язуючи або протиставляючи окремі висловлювання, а також виконує процедурні функції. У тому випадку, якщо учневі потрібні додаткові знання або способи дій, учитель виступає як майстер, допомагає придбати відсутній теоретичний або практичний досвід (Onopriienko).

Натепер існують різні класифікації проєктів. Найбільш характерні типи проєктів для зручності представлено на рис. 1.

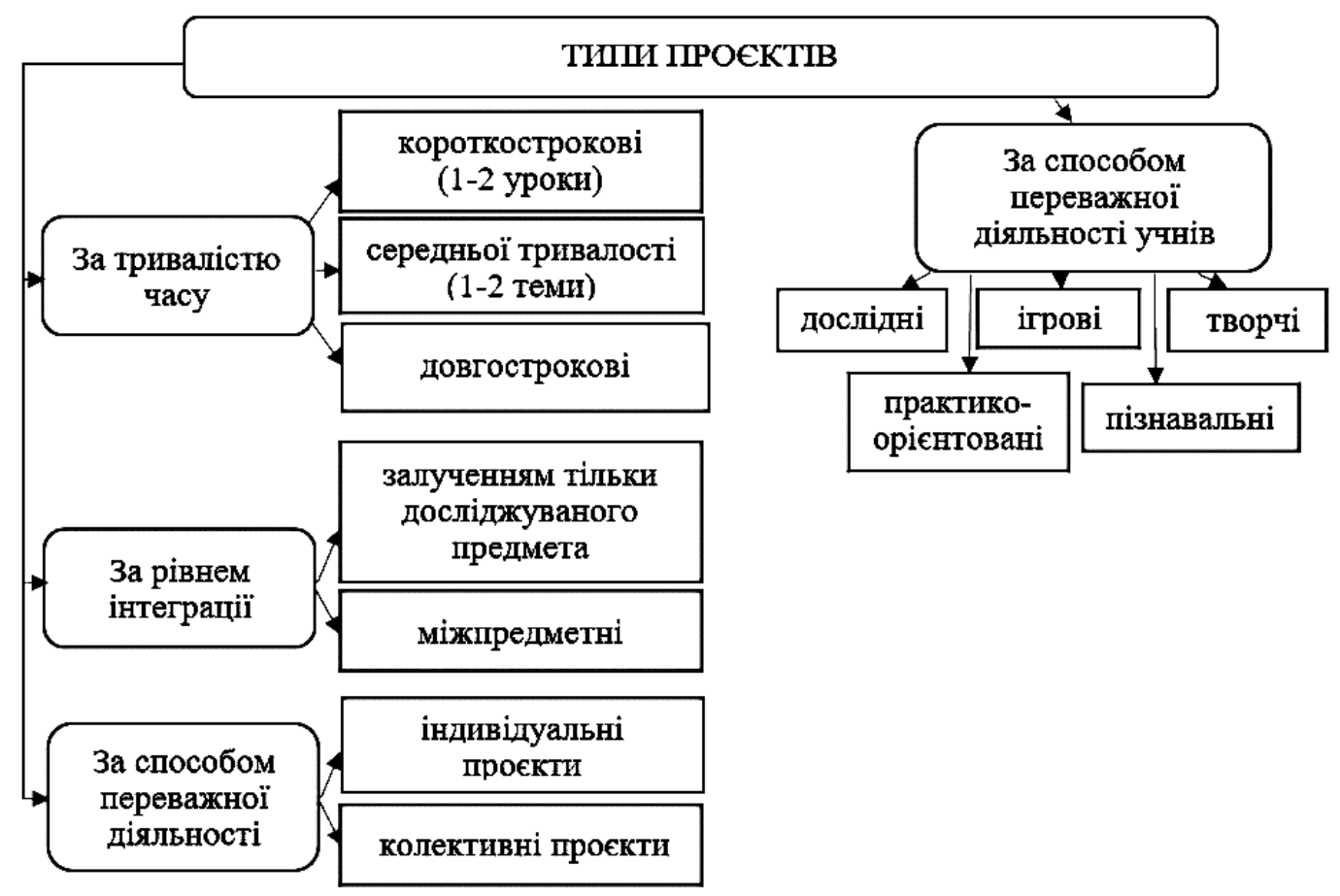

Рис. 1. Класифікація типів просктів 
Більш детально розглянемо блок класифікації за способом переважної діяльності учнів. Виділяють дослідні, ігрові, творчі, практикоорієнтовані, пізнавальні проєкти. Дослідницькі проєкти орієнтовані на розв'язання наукової проблеми, що містить виявлення актуальності теми дослідження, визначення завдань, предмета і об'єкта дослідження, визначення сукупності методів дослідження, шляхів вирішення проблеми, оформлення отриманих результатів.

В ігрових проєктах молодші школярі найчастіше приймають на себе певні ролі, зумовлені характером і змістом проєкту. Нерідко в ігрових ситуаціях переважає пригодницький сюжет: проєктування наукової експедиції 3 метою комплексного вивчення території на уроках Я досліджую світ, подорож з землепроходьцями з визначенням кілометражу пройденого маршруту на уроках математики.

Творчі проєкти не мають до кінця опрацьованої структури спільної діяльності, вона лише намічається і підпорядковується жанру кінцевого результату. Планованими результатами можуть бути створення свята, наукового журналу, відеофільму, виставка малюнків, буклетів, сайту, лепбуків тощо.

Пізнавальні проєкти спрямовані на збір інформації про який-небудь об'єкт, конструювання процесу і явища в конкретних умовах, розробка проєктів, спрямованих на вирішення глобальних проблем сучасності. Під час їх виконання ставиться мета, підбирається та аналізується наукова інформація, проводяться «мозкові атаки» 3 метою їх вирішення. Результат проєкту складається у вигляді карт, схем, доповіді (Білик, 2013, С. 6-8).

Практико-орієнтовані проєкти спрямовані на конкретний практичний результат і пов'язані 3 соціальними цінностями здобувачів початкової освіти: очищення водойм, сортування сміття, створення історичної хроніки населеного пункту тощо.

У цілому в проєктній діяльності молодших школярів виділяться такі етапи, відповідні структурі освітньої діяльності:

- мотиваційний (учитель: заявляє загальний задум, створює позитивний мотиваційний настрій; учні: обговорюють, пропонують власні ідеї);

- підготовчий (визначаються тема і цілі проєкту, формулюються завдання, виробляється план дій, встановлюються критерії оцінки результату і процесу, узгоджуються способи спільної діяльності спочатку з максимальною допомогою вчителя, пізніше 3 наростанням учнівської самостійності);

-інформаційно-операційний (учні: збирають матеріал, працюють 3 літературою та іншими джерелами, безпосередньо виконують проєкт, коли вчитель: спостерігає, координує, підтримує, сам є інформаційним джерелом);

- рефлексивно-оцінний (учні: представляють проєкти, беруть участь в колективному обговоренні та змістовної оцінки результатів і процесу роботи, здійснюють усну або письмову самооцінку, учитель виступає учасником колективної оціночної діяльності).

3 метою оптимізації проєктної діяльності дітей доцільно запропонувати їм у такий алгоритм:

1) проаналізуйте ваші проблеми;

2) виділіть ту проблему, вирішення якої для вас сьогодні найбільш важливо;

3) сформулюйте проблему у вигляді питання;

4) уявіть можливий результат вашої роботи;

5) продумайте послідовність дій по досягненню бажаного результату. Для цього дайте відповідь на питання: 3 чого необхідно почати? що необхідно зробити далі? що необхідно зробити на останньому етапі роботи?

6) визначте можливі джерела пошуку необхідної інформації. Проконсультуйтеся в разі необхідності з учителем;

7) дійте за наміченим планом;

8) продумайте форму подання i захисту результату вашої роботи;

9) проаналізуйте свою діяльність: чи відповідає результат задумом? що нового для себе дізналися в процесі роботи? чому навчилися? що було найважчим? що виявилося легким? чи можлива подальша робота над проєктом? якщо так, то в якому напрямку? (Лук'янова, 2009, С. 16-21).

Для прикладу розглянемо організацію діяльності дітей над проєктом по темі «Річки та водойми нашої місцевості». Проєкт носить дослідницький характер. Створення та реалізація проєкту відбувається на уроці «Я досліджую світ», так як цей курс є інтегрованим. У рамках такої роботи об'єднуються знання, вміння і способи діяльності дітей з областей «Навколишній світ», «Читання», «Українська мова», 
«Математика», «Інформатика», «Образотворче мистецтво».

На початковому етапі діти в основному визначають можливі джерела інформації по досліджуваній проблемі: бесіди 3 дорослими, книги, спостереження, досліди, Інтернет. Так на уроках математики розв'язують задачі, які пов'язані з довжиною річок, аналізують і придумують завдання для однокласників. На уроках читання підбираються тексти з відповідної тематики. Отже, на уроках 3 української мови діти записують найголовніші факти, водночас не відходячи від теми та плану уроку. Уроки інформатики безпосередньо допомагають дітям у зборі потрібної інформації. Так само учні створюють презентації за матеріалами пройдених уроків і позакласних заходів.

На наступному етапі діти аналізують і систематизують отриманні відомості, знаходять відповіді на питання. Потім оформляють результати дослідження у вигляді доповіді, електронної презентації, статті в шкільному журналі або в лепбуці. По завершенні роботи здійснюється публічний захист, в ході якої учитель оцінює процес і результати спільної діяльності дітей, а також здійснюється рефлексія діяльності учасниками проєкту.

Висновки i перспективи подальших досліджень. Отже, проєктна діяльність збагачує не тільки школярів, а й педагогів, адже спільна підготовка проєктів дозволяє відчути справжню спільність, партнерство з учнями, пережити творчий підйом, піднятися на новий рівень.

Педагогічна цінність проєктної діяльності полягає в збагаченні суб'єктивного досвіду дітей новими знаннями і способами діяльності, діти вчаться враховувати інтереси своїх однокласників, знаходити компроміси в суперечливих питаннях. Використання проєктів дозволяє розвивати творчі здібності, логічне мислення, прагнення самому відкривати нові знання і вміння виявляти їх в сучасній дійсності.

\section{ЛІТЕРАТУРА:}

1. Бібік Н. Нова українська школа: порадник для вчителя: підручник. Київ: Літера ЛТД, 2018. 160 с.

2. Білик В. Проєктна діяльність - основа розвитку творчих здібностей молодших школярів. Початкова школа, 2013. № 5. C. 6-8.

3. Використання проєктної технології у початковій школі. URL: http://osvita.ua/school/lessons_summary/ edu_technology/33260.

4. Бєляєв С. Підготовка студентів до використання проєктної технології. Педагогіка формування творчої особистості у вищій $і$ загальноосвітній школах : зб. наук. пр. / редкол.: Т. І. Сущенко (голов. ред.) та ін. Запоріжжя, 2009. Вип. 55. С. 31-34.

5. Державний стандарт початкової освіти URL: https://www.kmu.gov.ua/ua/npas/prozatverdzhennyaderzhavnogo-standartu-pochatkovoyi-osviti.

6. Зимняя И., Сахарова Т. Проектная методика обучения английскому языку. Иностранные языки в школе. 1991. № 3. C. $9-12$.

7. Коваленко Є. Проєктна технологія як засіб формування творчої особистості: історико-теоретичний аспект. Наукові записки Ніжинського державного університету імені Миколи Гоголя. Психолого-педагогічні науки : науковий журнал / гол. ред. Є. І. Коваленко. Ніжин : НДУ ім. М. Гоголя, 2011. № 3. С. 14-18.

8. Концепція Нової Української Школи : ухвалений рішенням колегії MOH 27 жовтня 2016 p. URL: https://inlnk.ru/WDDxk.

9. Лук'янова Л. Технологія організаціїпроєктноїдіяльності. Імідж сучасногопедагога. 2009. № 10 (99). С. 16 -21.

10. Онопрієнко О. Проєктна діяльність у початковій школі. URL: https://inlnk.ru/WyYQy

11. Освітні технології: навчально-методичний посібник / за ред. О. М. Пєхоти. Київ: АСК, 2002. 255 с.

\section{REFERENCES:}

1. Bibik N. M. (2018) Nova ukrainska shkola: poradnyk dlia vchytelia: pidruchnyk [New Ukrainian school: a guide for teachers: a textbook]. Kyiv: Litera LTD, 160 p. (in Ukrainian)

2. Bilyk V. Proektna diialnist - osnova rozvytku tvorchykh zdibnostei molodshykh shkoliariv [Project activity is the basis for the development of creative abilities of junior schoolchildren]. Pochatkova shkola, 2013. № 5. Pp. 6-8. (in Ukrainian)

3. Vykorystannia proektnoi tekhnolohii u pochatkovii shkoli [The use of project technology in primary school]. URL: http://osvita.ua/school/lessons_summary/edu_technology/33260. (in Ukrainian) 
4. Bieliaiev S. Pidhotovka studentiv do vykorystannia proektnoi tekhnolohii. Pedahohika formuvannia tvorchoi osobystosti u vyshchii i zahalnoosvitnii shkolakh [Preparing students to use project technology. Pedagogy of creative personality formation in higher and general education schools]. zb. nauk. pr. / redkol.: T.I. Sushchenko (holov. red.) ta in. Zaporizhzhia, 2009. V. 55. Pp. 31-34. (in Ukrainian)

5. Derzhavnyy standart pochatkovoyi osvity [State standard of primary education]. URL: https://www.kmu.gov.ua/ ua/npas/prozatverdzhennya-derzhavnogo-standartu-pochatkovoyi-osviti. (in Ukrainian)

6. Zymniaia Y., Sakharova T. Proyektnaya metodika obucheniya angliyskomu yazyku. Inostrannyye yazyki v shkole [Project methods of teaching English. Foreign languages at school]. 1991. № 3. Pp. 9-12. (in Russian)

7. Kovalenko Ye. Proektna tekhnolohiia yak zasib formuvannia tvorchoi osobystosti: istoryko-teoretychnyi aspect [Project technology as a means of forming a creative personality: historical and theoretical aspect]. Naukovi zapysky Nizhynskoho derzhavnoho universytetu imeni Mykoly Hoholia. Psykholoho-pedahohichni nauky : naukovyi zhurnal / hol. red. Ye. I. Kovalenko. Nizhyn : NDU im. M. Hoholia, 2011. № 3. Pp. 14-18. (in Ukrainian)

8. Kontseptsiia Novoi Ukrainskoi Shkoly : ukhvalenyi rishenniam kolehii MON 27 zhovtnia 2016 r. [The concept of the New Ukrainian School: approved by the decision of the Board of the Ministry of Education and Science on October 27, 2016.] URL: https://inlnk.ru/WDDxk (in Ukrainian)

9. Lukianova L. Tekhnolohiia orhanizatsii proektnoi diialnosti [Technology of organizing project activity]. Imidzh suchasnoho pedahoha. 2009. № 10 (99). Pp. 16-21. (in Ukrainian)

10. Onopriienko O. Proektna diialnist u pochatkovii shkoli [Project activity at the cobbled schools]. URL: https:// inlnk.ru/WyYQy (in Ukrainian)

11. Osvitni tekhnolohii: navchalno-metodychnyi posibnyk [Osvitni technologies: initial-methodical guide] / za red. O.M. Piekhoty. Kyiv: ASK, 2002. 255 p. (in Ukrainian) 